\title{
Selânikli Necib Dede'nin Sûzinâk Âyini'nin Birinci Selâmının Makam ve Geçki Bakımından Analizi
}

\section{Nihat Ozan KÖROĞLU', Gamze Nevra KÖROĞLU}

Öz: Dini Mûsiki formlarından Tekke Mûsikisi formu içerisinde yer alan Mevlevî Âyinleri, bestelenmeye başlandığı dönemden itibaren Türk Mûsikisinin en sanatlı eserlerinden biri haline gelmiştir. Âyinlerin bu derece önemli bir yere sahip olmasının başlıca nedenleri, Türk Mûsikisinin yapı taşları olan çeşni, makam, geçki ve usûl gibi ögeler bakımından zengin ve öğretici bir özelliğe sahip olmalarıdır. Böyle özelliklere sahip bir formun ayrıntılı bir şekilde analizinin yapılması Türk Mûsikisinin sahip olduğu zenginliği ortaya çıkarmak adına önemli bir nitelik taşımaktadır. Bu makalede, Selânikli Necib Dede'nin sûzinâk âyininin birinci selâmı makam ve geçki açısından incelenmiş, biçim analizi ve melodik analiz yapılarak benzerlikler ve farklııklar tespit edilmiştir.

Anahtar Kelimeler: Mevlevî âyini, makam, geçki, biçim analizi, melodik analiz.

\section{$\underline{\underline{ }} \mathrm{=}$ \\ The Analysis of Necib Dede's, from Thessaloniki, First Ave of Suzinik Ritual in Terms of Modal Structures and Route}

Abstract: Classified within Tekke music, one of the religious music forms, Mevlevî Rituals have become one of the most artistic works of Turkish music since the period they were composed. Main reasons of rituals having so much significance are that Turkish music has a rich and pragmatic feature in terms of flavor, modal structures, route and tempo which are building stones. A detailed analysis of a form with these features is important in terms of revealing the richness of Turkish music. In this article, first ave of sûzinâk ritual of Necib Dede from Thessaloniki has been analyzed in terms of modal structures and route and form analysis and melodic analysis have been carried out to determine the similarities and differences.

Keywords: Mevlevî ritual, modal structures, route, form analysis, melodic analysis.

' Yrd. Doç.Dr., Ömer Halisdemir Üniv., Türk Mûsikisisi Devlet Konservatuvarı, nayiozan@hotmail.com.

ii Öğr. Gör., Ömer Halisdemir Üniv., Türk Mûsikisisi Devlet Konservatuvarı, nevragulser@hotmail.com. 


\section{Giriş}

Hz. Mevlânâ'nın düşünce yapısını temel alarak, Sultan Veled tarafından kurulan Mevlevîlik Tarikatı'nda, mûsiki ayrı bir öneme sahiptir. Çünkü Mukâbele adı verilen Mevlevî zikri içerisinde mûsiki, Âyin formuyla gelişmiş ve gelenekleşmiştir (Özalp, 1992: 49).

Sultan Veled zamanı ve sonrasında Semâ törenlerinde, bestelenen Âyinler icra edilmeye başlamıştır. Bu eserler Klasik Türk Mûsikisi sistemi içerisinde dini duyguları ifade eden bir üslup çerçevesinde bestelenmiş Âyin-i Şeriflerdir (Küçük, 2003: 378). Bu noktada Mevlevî Âyini, Semâ, Mukâbele ve Âyin-i Şerif terimlerinin anlamları arasındaki ayrımı da ifade etmek yararlı olacaktır. Mevlevî Âyini (Semâ veya Mukâbele), gerçekleştirilen bu ritüelin genel adıdır. Âyin-i Şerif ise bu ritüel sırasında icra edilen, sözleri Mevlânâ'ya bestesi Itri'ye ait olan rast makamındaki Na't-ı Mevlânâ ile başlayıp, peşrev, dört selâm, son peşrev ve son yürük semâi ile biten mûsiki formudur (Tanrıkorur, 2003: 133).

Türk Din Mûsikisinde önemli bir yeri olan ve Türk Din Mûsikisi formları içinde büyük ve özel bir konuma sahip olan Mevlevî Âyini, Mevlid ve Miraciyeden sonra Türk Din Mûsikisinin en büyük üçüncü formudur. Mevlevî Âyini, yapısı itibari ile diğer formlardan farklı olarak kendine özgü bir inanç ve anlam dünyasına sahiptir. Bu bağlamda insan, toplum, kâinat ve kıyâmet gibi unsurları da içerisinde barındıran Mevlevî Âyini formu ayrıntılı bir şekilde ele alınmalıdır (Bayrakçı, 2015: 139).

\section{Mevlevî Âyini (Âyin-i Şerif)}

Âyin (ritüel), kelime olarak Farsça kökenli olup, görenek, resim, adet, düzen, tören anlamına gelir ve tarikatlarda özel bir mûsiki eşliğinde zikir veya raks şeklinde yapılan törensel etkinliği ifade eder. Âyin, genellikle belirli kurallar çerçevesinde gerçekleştirilir. Burada Mevlevî Âyini, Rifai Âyini, Bektaşi Âyini örnek olarak verilebilir (Öztuna, 2006: 134 C1).

Mevlevî tarikatında Semâ sırasında icra edilmek üzere Mevlevî ve diğer bestekârlarca belirli makam ve usûller gözetilerek bestelenmiş, bir peşrev, dört selâmdan meydana gelen ve güfteleri genellikle Hz. Mevlânâ'nın Mesnevî, Divân-ı Kebir ve Rubâilerinden alınan dini mûsiki formlarından biri olan tekke mûsikisi formunun en büyüklerindendir. Mevlevî Âyini her birine selâm adı verilen dört bölümden oluşur (Ak, 2011: 172-173). Bu selâmlardan ilki çalışmamızın konusunu da içeren ve peşrevden sonra icra edilen birinci selâmdır.

Birinci selâm denilen bu bölümde semâzenler hem kendi etrafında hem de semâhane etrafında dönerler. Birinci selam insanın Allah'ın yüceliğini bilmesi ve kendi kulluğunu idrak etmesi anlamına gelir (Özkan, 2008: 49). Mevlevî Âyinlerinin birinci selâmı genellikle 14 zamanlı Devr-i Revan usûlünde bazen de 8 zamanlı Düyek usûlünde bestelenmiştir (Tanrıkorur, 2003: 123). Âyinlerin en uzun sözlü bölümlerinden biri olan birinci selâmlar, âyine adını veren makamla başlayıp 
çoğunlukla makamın karar sesi veya güçlü sesinde sonlanır (Akdoğu, 1995: 445; aktaran Anıtsoy, 2006: 12). Aynı zamanda birinci selâm insanın kendi kulluğunun farkına varması anlamına da gelmektedir (Tanrıkorur, 2003: 171).

Mevlevî Âyini gerek beste, güfte ve icra açısından gerekse çalgı ve repertuvar zenginliği açısından Türk Mûsikisinde önemli bir yere sahiptir (Bayrakçı, 2015: 150). Rauf Yektâ Bey 1934 yılında İstanbul Konservatuarı tarafından yapılan "Mevlevî Âyinleri" neşriyatının önsözünde İstanbul Konservatuarı Tasnif ve Tesbit Heyeti Reisi sıfatıyla şöyle demektedir:

“Türk Mûsikisi'nin mükemmel bir târihi yazıldığında görülecektir ki, en meşhur Türk bestekârlarının hepsi Mevlevidirler. Bu üstadlar mûsiki sahâsındaki zekâ ve dehâlarının en büyük kısmını Mevlevî Âyinleri bestelemeye sarfetmişlerdir. Bunun içindir ki Mevlevî Âyinleri, Türk Mûsikisi'nin en sanatlı parçalarını hâvi (içeren) bedialar (kıymetler) hazinesi hâlini almıstır. Mûsiki üstadlarımız, milli mûsikimizin gavâmızını (inceliklerini) ögrenmek için mutlaka Mevlevî Âyinleri'ni tetebbu' etmek (derinligine incelemek) lüzûmunu sakirdlerine (ögrencilerine) tavsiyeden hali' (kayıtsız) kalmazlardı. Filhakika (gerçekten de) güzel sanatların mûsiki kısmında Türklerin ne derece muvaffak olduklarını anlamak ve asrımızda da Türk rûhuna hitâb edecek eserler yazabilmek için ecdadımızdan kalan bu nefis yâdigârları ciddi sûrette tedkikden başka çâre yoktur" (aktaran Kılınçarslan, 2006: 1).

Bugüne kadar tespit edilebilen 138 âyinin dördünün bestekârı bilinmemektedir. Ayrıca geriye kalan 134 âyinin on altısı da günümüze kadar gelememiştir. Bu âyinler; Hafız Şeyda'nın hicazeyn ve ısfahan âyini, İsmet Ağa'nın ısfahan, rahatfeza ve müstear âyini, Nasır Abdülbaki Dede'nin ısfahan âyini, Dede Efendi'nin ısfahan âyini, Yahya Efendi'nin ısfahan âyini, Arif Hikmeti Dede'nin mahur âyini, Künhi Abdürrahim Dede'nin nühüft âyini, Kudümzen Ali Dede'nin nühüft âyini, Vardakosta Ahmed Ağa'nın sabâ âyini, Selânikli Necib Dede'nin sûzinâk âyini, Haşim Bey'in şehnaz âyini, Kamil Efendi'nin yegâh âyini, Abdülkerim Dede'nin yegâh âyini ve Nesib Dede'nin suzidil âyinidir (Öztuna, 2006: 134 C.I).

Necib Dede'nin sûzinak âyini unutulmuş 16 eser arasında yer almaktadır. Ayrıca Öztuna'nın (2006: 101 c.II) Ansiklopedik Sözlüğü’nde Necib Dede başlığı altında şu ifadeler yer almaktadır: "Necib Dede (Selânikli Neyzen) (-1883) Herhalde Selânik Mevlevihanesi'ndendi. Sûzinâk âyini kaybolmuștur." Ancak Necib Dede'nin sûzinâk âyini yakın tarihte yeniden gün yüzüne çıkmış ve icra edilmeye başlanmıştır.

Tanrıkorur'a (2003: 125) göre Mevlevî Âyinlerinde makam ve usûller nazariyat kitaplarından daha ayrıntılı bir şekilde ele alınmış, seçilen şiirler ve bu şiirlerin bestelenmesi sırasında kullanılan usûller titiz bir şekilde uygulanmıştır. Bu sebeple Türk Mûsikisinde saz ve ses icracıları Mevlevî Âyinlerini kendilerine örnek 
eser olarak görmüşlerdir. Bu sebeple Necib Dede'nin sûzinâk âyininin müzikal olarak incelenmesi, daha önce incelenmemiş olması sebebiyle büyük öneme sahiptir. Saklı kalan bu müzikal özelliklerin ortaya çıkartılması Türk Mûsikisi ve Türk Mûsikisinin gelecek kuşaklara aktarılması adına mühimdir. Araştırmada Necib Dede'nin sûzinâk âyinin birinci selâmının makamsal olarak analizi yapılmış ve seyir özellikleri belirlenmiştir.

\section{Yöntem}

Bu makalede, Necib Dede'nin sûzinâk âyininin birinci selâmının müzikal boyutta (1) Sûzinâk Âyinin Birinci Selâmının Biçim Analizi, (2) Sûzinâk Âyinin Birinci Selâmının Melodik Tekrar Analizi, (3) "1.A Cümlesi”nin Analizi, (4) "1.B Cümlesi”nin Analizi, (5) “1.C Cümlesi”nin Analizi, (6) “1.D Cümlesi”nin Analizi, (7) “1.E Cümlesi”nin Analizi, (8) “1.F Cümlesi”nin Analizi, (9) “1.G Cümlesi”nin Analizi, (10) "1.H Cümlesi”nin Analizi yapılarak; eserin teknik ve müzikal anlamda sahip olduğu makamsal yapısı, geçkileri, biçimsel yapısı, melodik tekrar durumu ve ölçü yapısı özellikleri ortaya konmuştur.

\section{Bulgular ve Analiz}

Bu bölümde Necib Dede'nin sûzinâk âyininin birinci selâmı makam ve geçki ögeleri açısından analiz edilmiştir. Bu analiz yapılırken "zirgüleli sûzinâk makamı" Arel-Ezgi-Uzdilek sistemine göre ele alınmıştır. Bu sisteme göre zirgüleli sûzinâk makamının özellikleri şu şekilde ifade edilebilir:

Durağı: Rast perdesidir.

Seyri: İnici-çıkıcıdır.

Güçlüsü: Nevâ perdesidir.

Dizisi: Zirgüleli hicaz makamı dizisinin rast perdesindeki şeddidir. Rast perdesinde bir hicaz beşlisine, nevâ perdesinde bir hicaz dörtlüsünün eklenmesinden oluşur.

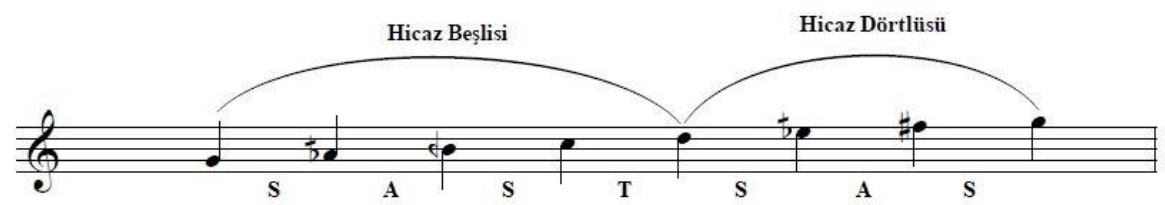

Şekil 1. Sûzinâk Makam Dizisi.

Asma Karar Perdeleri: Çargâh perdesinde nikriz çeşnisi ve makamın karakteristik özelliği olan segâh perdesi üzerinde hüzzam çeşnili asma kararlar yapılır. 


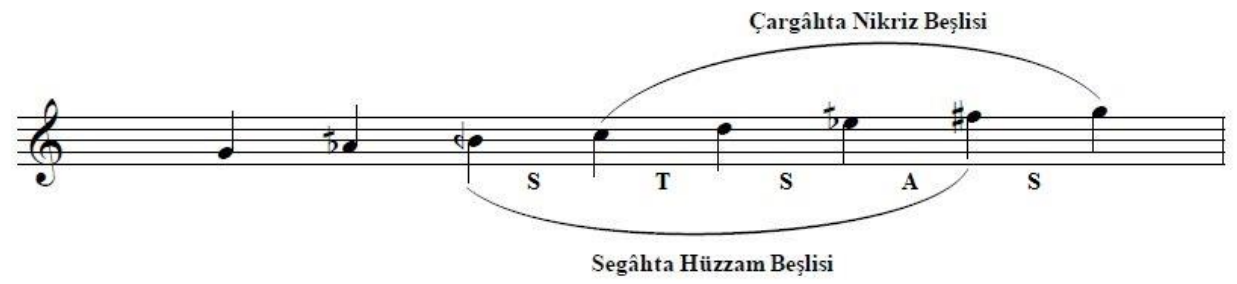

Şekil 2. Sûzinâk Makamı Asma Karar Perdeleri.

Genişlemesi: Makam tiz bölgeye olmak üzere iki şekilde genişler. genişler.

1. Rast perdesindeki hicaz beşlisi gerdâniye perdesi üzerine simetrik

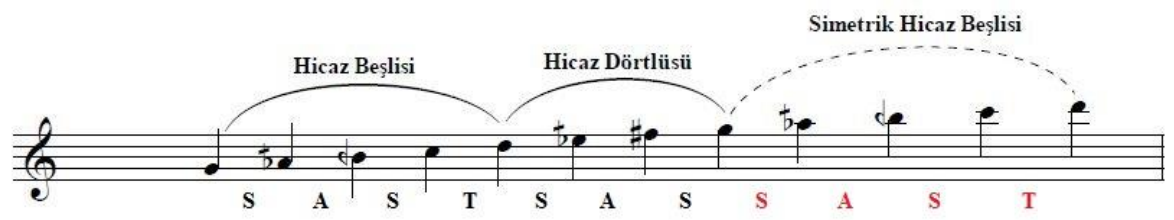

Şekil 3. Sûzinâk Makamı Birinci Genişlemesi.

2. Nevâ perdesindeki hicaz dörtlüsüne gerdâniye perdesinde bir bûselik beşlisi eklenmesi ile nevâ perdesinde hümâyûn makam dizisi oluşur (Özkan, 2000: 236-237).

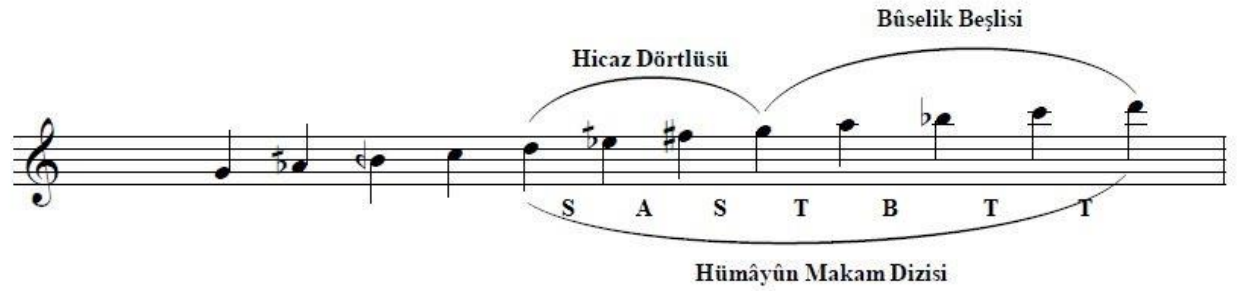

Şekil 4. Sûzinâk Makamı İkinci Genişlemesi.

Analizlerde Karadeniz'in (2013) “Mevlevî Âyinlerinin Kompozisyon Açısından İncelenmesi” isimli doktora tezinden ilham alınarak biçim ve melodik tekrar unsurları temel alınmış ve bu şekilde bir sınıflandırma yoluna gidilmiştir.

Ayrıca çalışma kapsamında analizi yapılan Necib Dede’nin sûzinâk âyininin birinci selâmının notaları, Ahmet Çalışır'ın “Beste-i Kadimden Beste-i Cedide (Meydan Görmüş) Mevlevî Âyinleri” adlı iki ciltlik kitabından temin edilmiştir. 


\subsection{Sûzinâk Âyinin Birinci Selâmının Biçim Analizi}

Bu analizde güfte ve müzikal ifadeye dikkat edilmiş ve her müzikal ifadenin başlangıç ve bitişi arasındaki müzik cümlesi büyük harf ile sembolleştirilmiştir. Âyinin birinci selâmı incelendiğinde büyük harflerin birinci selâma ait olduğunu belirtmek için cümleler $1 \mathrm{~A}, 1 \mathrm{C}, 1 \mathrm{~F}$ vb. şeklinde yazılmıştır. Müzik cümlesi içerisindeki her ölçü ise $1,2,3 \ldots .$. şeklinde numaralandırılmıştır. Böylece birinci selâmın 4 ölçü olan ilk müzik cümlesi şu şekilde gösterilmiştir:

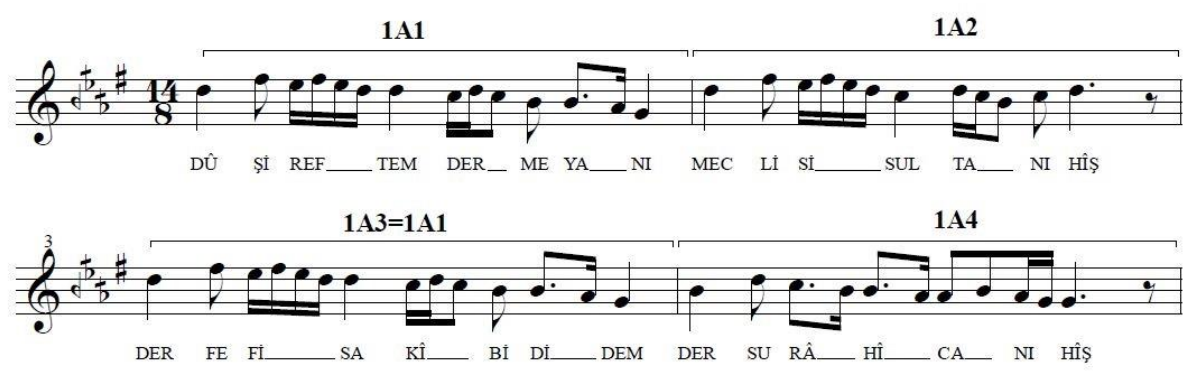

Şekil 5. Birinci Selâmın 1A Müzik Cümlesinin Ölçülere Göre Dağılımı.

Şekil 5’te görüldüğü gibi birinci selâmın ilk müzik cümlesi olan $1 \mathrm{~A}$ cümlesi 4 ölçüden oluşmaktadır. Bunlar $1 A 1,1 A 2,1 A 3$ ve $1 A 4$ ölçüleridir. Burada $1 A 3$ ölçüsü birinci ölçü ile aynı olduğundan $1 A 3=1 A 1$ şeklinde gösterilmiştir. Ayrıca $1 A, 1 B, 1 C$ şeklinde belirtilen ve biçimi oluşturan bu bölümler bize birinci selâmın kaç müzik cümlesinden oluştuğunu göstermektedir. Birinci selâmın analizinde müzik cümleleri içerisinde birbirinden çok az farklılıklar arz eden müzik cümleleri benzerlik taşıdığı ölçünün sembolü üzerine ' işareti konularak (1A1') şeklinde gösterilmiştir. Benzer ölçünün de benzeri olan ölçülerde ise "işareti (1A1") şeklinde bir kez arttırılmıştır (Bkz: Şekil 6).

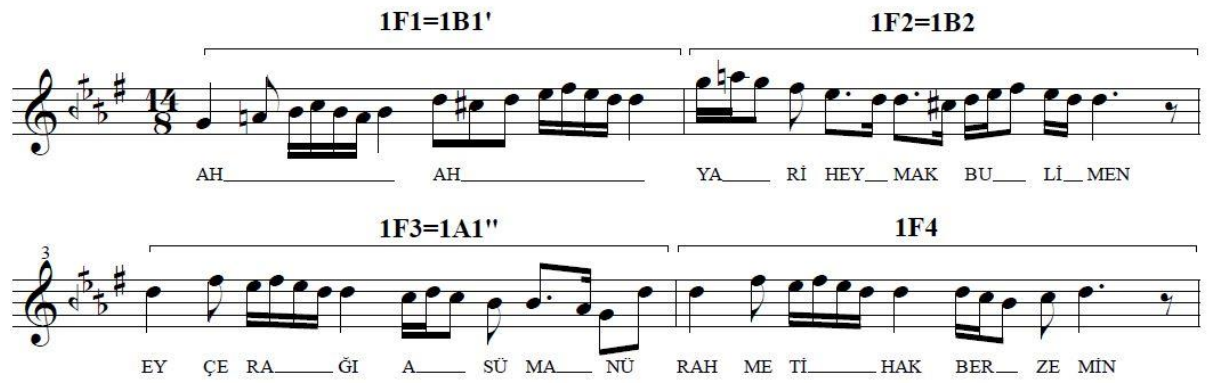

Şekil 6. Birinci Selâmın 1F Müzik Cümlesinin Illk Dört Ölçüsünde Benzer Ölçülerin Gösterimi. 
Şekil 6'da 1F cümlesinin ilk dört ölçüsü görülmektedir. Burada ilk ölçü olan 1F1 ile 1B1 ölçüsünün birinci çeşitlemesi aynıdır ve bu sebeple Şekil 6'daki gibi gösterilmiştir. Aynı şekilde $1 \mathrm{~F}$ cümlesinin üçüncü ölçüsü olan $1 \mathrm{~F} 3$ ile $1 \mathrm{~A} 1$ ölçüsünün ikinci çeşitlemesi aynı olduğundan $1 \mathrm{~F}_{3}=1 \mathrm{~A} 1$ " şeklinde sembolize edilmiştir.

\subsection{Sûzinâk Âyinin Birinci Selâmının Melodik Tekrar Analizi}

Çalışma kapsamında analizi yapılan Necib Dede'nin sûzinâk âyininin birinci selâmı 49 ölçüden oluşmaktadır. Birinci selâmda 8 müzik cümlesi tespit edilmiş, bu müzik cümleleri $1 \mathrm{~A}, 1 \mathrm{~B}, 1 \mathrm{C}, 1 \mathrm{D}, 1 \mathrm{E}, 1 \mathrm{~F}, 1 \mathrm{C}$ ve $1 \mathrm{H}$ şeklinde sınıflandırılmış ve tabloda bölümlerin ayrımının rahat yapılabilmesi açısından farklı renklerle gösterilmiştir (Bkz: Tablo 1).

Tablo 1. Birinci Selâmın Ölçülere Göre Dağılımı.

\begin{tabular}{|c|c|c|c|c|c|c|c|c|c|c|}
\hline : & 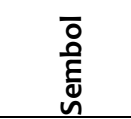 & : & $\begin{array}{l}\bar{o} \\
\text { है } \\
\tilde{\nu}\end{array}$ & : & $\begin{array}{l}\bar{\delta} \\
\text { है } \\
\text { ص్ }\end{array}$ & 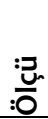 & $\begin{array}{l}\bar{\delta} \\
\text { है } \\
\tilde{\nu}\end{array}$ & : & & 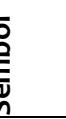 \\
\hline 1 & 1A1 & 11 & $1 C_{1}=1 B 1$ & 21 & $1 D_{3}=1 A_{1}$ & 31 & $1 F_{3}=1 A 1 "$ & 41 & 1G7 & 1H1 \\
\hline 2 & $1 \mathrm{~A} 2$ & 12 & $1 C_{2}=1 B 2$ & 22 & $1 D_{4}=1 A_{4}$ & 32 & $1 \mathrm{~F} 4$ & 42 & \multicolumn{2}{|c|}{$1 \mathrm{H} 2=1 \mathrm{~B} 2$} \\
\hline 3 & $1 A_{3}=1 A_{1}$ & 13 & $1 C_{3}$ & 23 & $1 \mathrm{E}_{1}$ & 33 & $1 F_{5}=1 A 1 "$ & 43 & \multicolumn{2}{|c|}{$1 \mathrm{H}_{3}=1 \mathrm{C}^{\prime}$} \\
\hline 4 & 1A4 & 14 & $1 \mathrm{C}_{4}$ & 24 & $1 \mathrm{E}_{2}$ & 34 & $1 F 6=1 A 4$ & 44 & \multicolumn{2}{|c|}{$1 \mathrm{H}_{4}=1 \mathrm{C}_{4}$} \\
\hline 5 & 1B1 & 15 & $1 C_{5}$ & 25 & $1 \mathrm{E}_{3}$ & 35 & $1 \mathrm{G} 1=1 \mathrm{E} 1$ & 45 & \multicolumn{2}{|c|}{$1 \mathrm{H}_{5}=1 \mathrm{C}^{\prime}$} \\
\hline 6 & $1 \mathrm{~B}_{2}$ & 16 & $1 C 6=1 A 1 '$ & 26 & $1 \mathrm{E}_{4}$ & 36 & $1 \mathrm{G}_{2}=1 \mathrm{E} 2^{\prime}$ & 46 & \multicolumn{2}{|c|}{$1 H 6=1 A_{1} " \prime$} \\
\hline 7 & 1B3 & 17 & $1 C_{7}$ & 27 & $1 \mathrm{E}_{5}=1 \mathrm{~B} 5$ & 37 & $1 G_{3}$ & 47 & \multicolumn{2}{|c|}{$1 \mathrm{H}_{7}=1 \mathrm{C}^{\prime}{ }^{\prime}$} \\
\hline 8 & 1B4 & 18 & $1 C 8=1 A 4$ & 28 & $1 E 6=1 A 4 '$ & 38 & $1 \mathrm{G}_{4}$ & 48 & \multicolumn{2}{|c|}{$1 \mathrm{H} 8=1 \mathrm{~A} 4$} \\
\hline 9 & 1B5 & 19 & 1D1 & 29 & $1 F 1=1 B 1^{\prime}$ & 39 & $1 G_{5}$ & 49 & \multicolumn{2}{|c|}{$1 \mathrm{H} 9=1 \mathrm{~A} 4$} \\
\hline 10 & $1 B 6=1 A 4^{\prime}$ & 20 & $1 D_{2}=1 C_{4}$ & 30 & $1 F 2=1 B_{2}$ & 40 & $1 \mathrm{G} 6$ & & & \\
\hline
\end{tabular}

Tablo 1'de birinci selâmın ölçülere göre dağılımı gösterilmiștir. Ayrıca 41. ölçüde (1 1 cümlesinin yedinci ölçüsünde) müzik cümlesi ölçünün yarısında bittiği için iki kısma ayrılmış ve yarısı $1 \mathrm{G}$ cümlesinde yarısı ise $1 \mathrm{H}$ cümlesinde olmak üzere tablodaki gibi gösterilmiştir.

\section{3. "1.A Cümlesi”nin Analizi}

Birinci selâmın ilk müzik cümlesi olan $1 \mathrm{~A}$ cümlesi dört ölçüden oluşmaktadır. $1 A 1$ ve $1 A 2$ ölçüleri aynı melodik yapıyla başlamış fakat ölçü 
sonunda farklı bir seyir özelliği göstermişlerdir. 1A3 ölçüsü $1 A 1$ ölçüsünün aynısı olduğu için $1 \mathrm{~A} 3=1 \mathrm{~A} 1$ şeklinde gösterilmiştir.

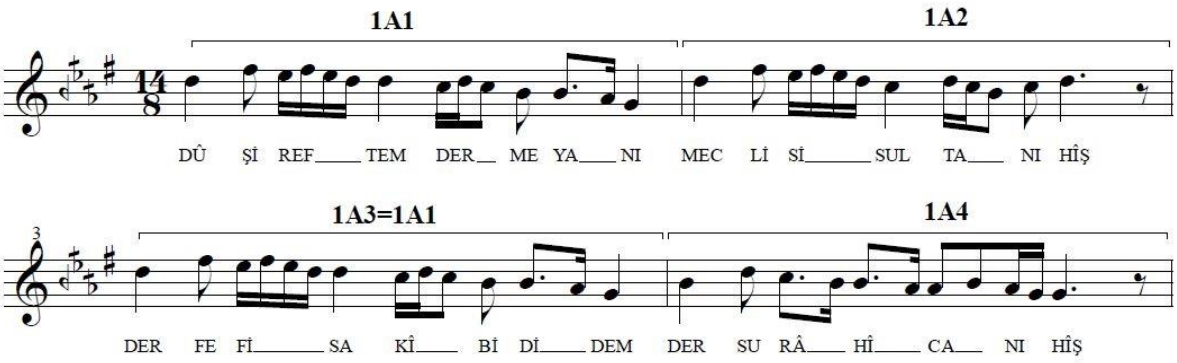

Şekil 7. 1A Cümlesi.

Şekil 7’ye bakıldığında, 1A1 ölçüsünde zirgüleli sûzinâk makamının güçlü perdesi olan nevâ perdesinden seyre başlanmış ve nevâ perdesinde hicaz çeşnisi kullanılıp makamın karar sesi olan rast perdesinde hicaz çeşnisi ile tam kalış yapılmıştır. 1A2 ölçüsünde çargâhta nikriz gösterilip makamın güçlüsünde yarım kalış yapılmıştır. 1A3 ölçüsü ile 1A1 ölçüsü aynıdır. 1A4 ölçüsünde ise rast perdesi üzerinde hicaz beşlisi kullanılarak tam kalış yapılmıştır.

\section{4. "1.B Cümlesi”nin Analizi}

Birinci selâmın ikinci müzik cümlesi olan 1B cümlesi altı ölçüden oluşmaktadır. 1B cümlesinin çoğunda ölçüler biçim ve melodik yapı açısından farklılık göstermekle birlikte makamın karara gidiş seyir özelliği gösteren 1B6 ölçüsü, 1A cümlesinin son ölçüsü olan 1A4 ölçüsünün birinci çeşitlemesidir.

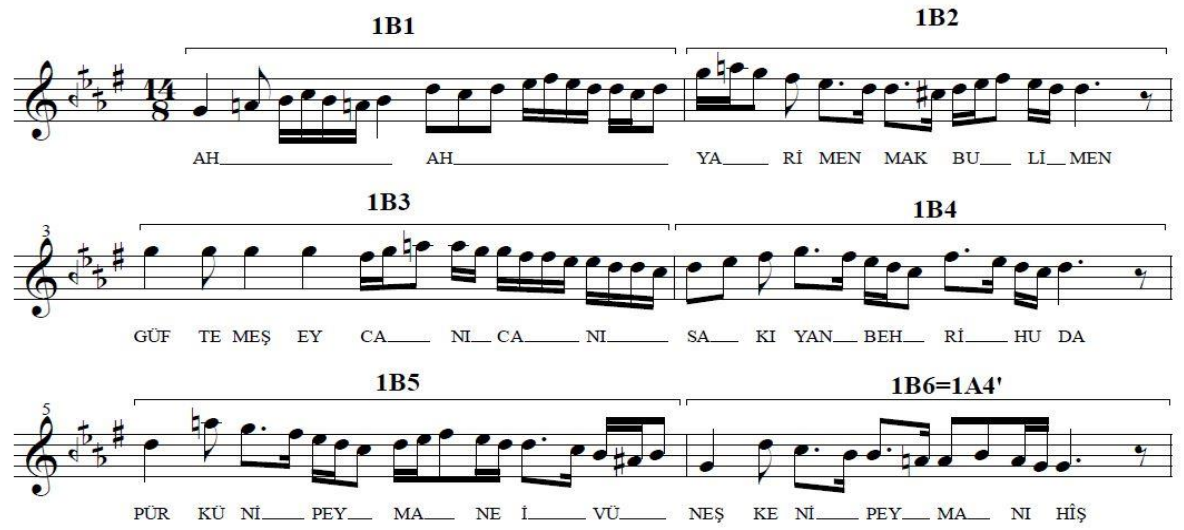

Şekil 8.1B Cümlesi. 
Şekil 8'e bakıldığında, 1B1 ölçüsünde rast perdesi üzerinde rast çeşnisi gösterilmiş ardından nevâ perdesinde kalınmıştır. Burada basit sûzinâk makamına bir geçki yapıldığı söylenebilir. 1B2 ölçüsünde nevâ perdesinde hicaz çeşnili yarım kalış yapılmış ve bu çeşni nim hicaz perdesi ile yedenlenmiştir. 1B3 ve 1B4 ölçülerinde ise nevâ perdesinde hicaz çeşnisi kullanılıp yine nevâ perdesi üzerinde yarım kalış yapılmıştır. 1B5 ölçüsünde nevâ perdesinde hicaz çeşnili seyrin ardından segâh perdesi üzerinde segâh çeşnisi gösterilmiştir. Burada hüzzam makamına küçük bir geçki yapıldığı söylenebilir. $1 \mathrm{~B} 6$ ölçüsü ise 1A4 ölçüsünün birinci çeşitlemesidir ve 1A4' şeklinde gösterilmiştir. Burada rast perdesinde rast çeşnisi yapılarak basit sûzinâk makamına geçilmiştir.

\section{5. "1.C Cümlesi"nin Analizi}

Birinci selâmın üçüncü müzik cümlesi olan $1 C$ cümlesi sekiz ölçüden oluşmaktadır. Bu cümlede 3, 4, 5 ve 7. ölçüler kendine özgü melodik yapılara sahiptirler. Bu ölçülerin dışında kalan ölçüler ise ya birinci selâm içerisinden başka bir ölçünün aynısı ya da çeşitlemesi şeklindedir.
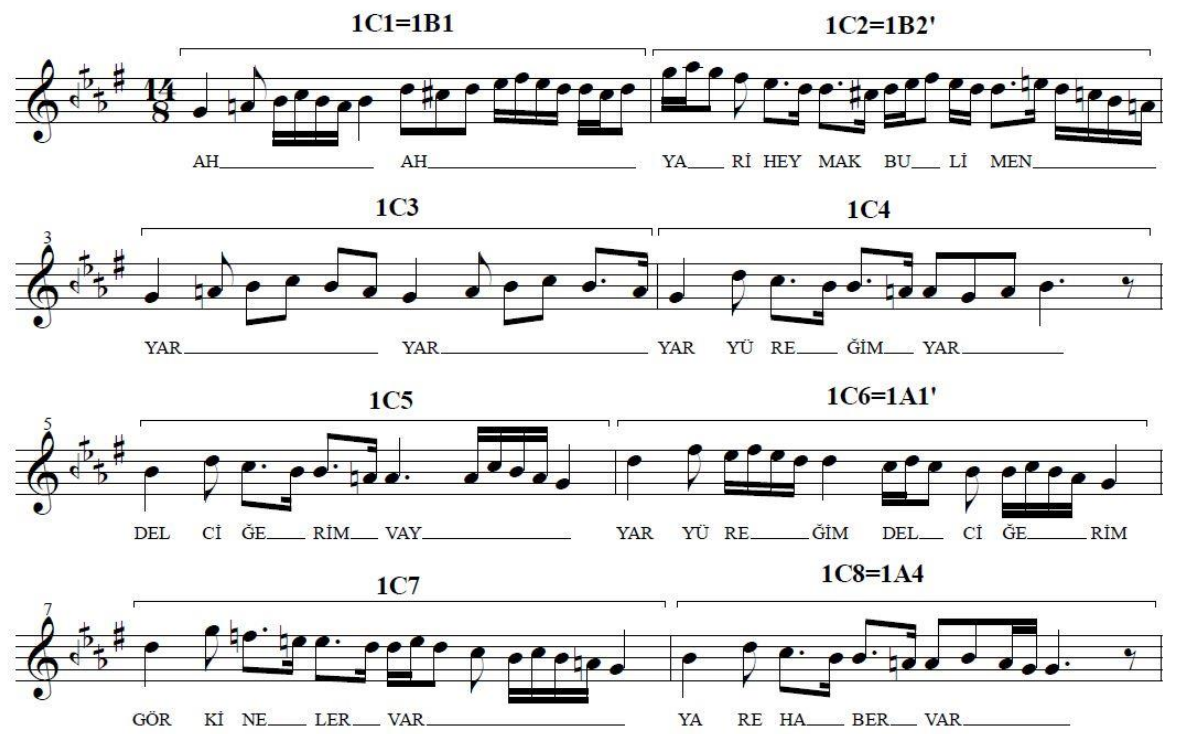

Şekil 9. 1C Cümlesi.

Şekil 9'da 1C1 ölçüsü 1B1 ölçüsü ile aynıdır. 1C2 ise 1B2 ölçüsünün birinci çeşitlemesidir ve 1B2' şeklinde gösterilmiştir. $1 C_{3}, 1 C_{4}$ ve $1 C_{5}$ ölçülerinde ise rast perdesi üzerinde rast çeşnisi gösterilmiştir. 1 C6 ölçüsünde ise yeniden ana diziye dönülerek rast ve nevâ perdelerinde hicaz çeşnisi kullanılmıştır. Ayrıca 1C6 ölçüsü $1 A 1$ ölçüsünün birinci çeşitlemesi olup 1A1' şeklinde gösterilmiştir. $1 C 7$ ölçüsünde nevâ perdesinde bûselik çeşnisi ve rast perdesinde ise rast çeşnisi kullanılarak inici rast makamı dizisi gösterilmiştir. 1C8 ölçüsü ise $1 A 4$ ölçüsü ile aynıdır. 


\section{6. “1.D Cümlesi”nin Analizi}

Birinci selâmın dördüncü cümlesi olan 1D cümlesi dört ölçüden oluşmaktadır. Bu cümlede sadece birinci ölçü olan 1D1 ölçüsü kendine özgü melodik yapıda, diğer üç ölçü ise $1 A$ ve $1 C$ cümlelerindeki birkaç ölçüden oluşmaktadır.

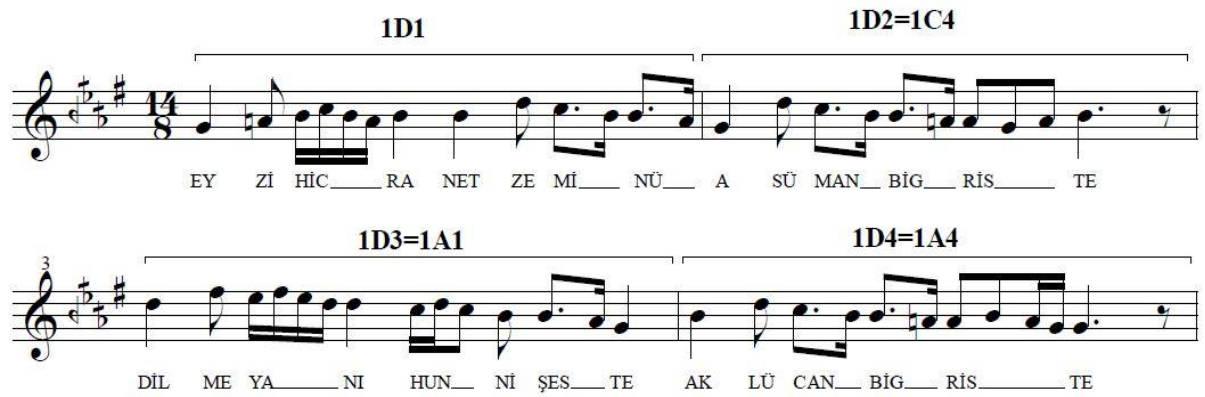

Şekil 10. 1D Cümlesi.

Şekil 10’a bakıldığında 1D1 ölçüsünde rast çeşnisi kullanılmıştır. 1D2 ölçüsü 1C4 ölçüsü ile aynıdır. 1D3 ölçüsü 1A1 ölçüsü ile aynıdır. 1D4 ölçüsü ise 1A4 ölçüsü ile aynı özellikleri taşımaktadır.

\section{7. "1.E Cümlesi"nin Analizi}

Birinci selâmın beşinci müzik cümlesi olan $1 \mathrm{E}$ cümlesi altı ölçüden oluşmaktadır. $1 \mathrm{E}$ cümlesinin ilk dört ölçüsü biçim ve melodik yapı açısından farklılık göstermekle birlikte, cümlenin son iki ölçüsü $1 B$ cümlesinin son iki ölçüsünün aynısıdır.
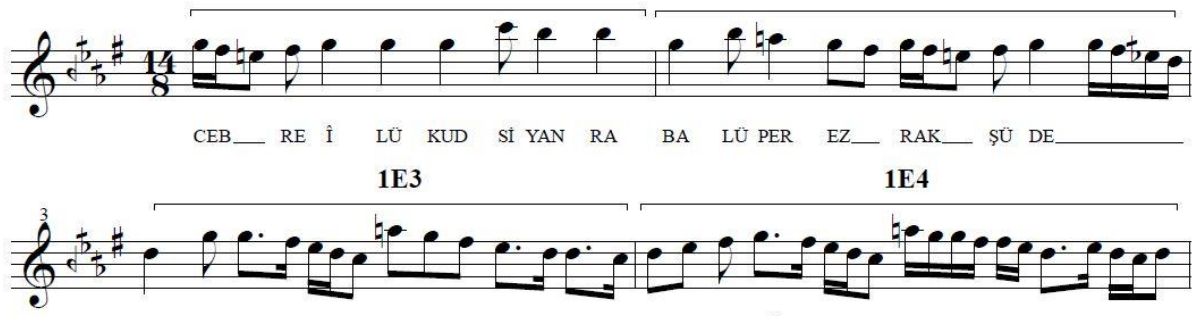

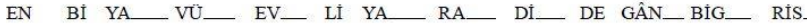
TE

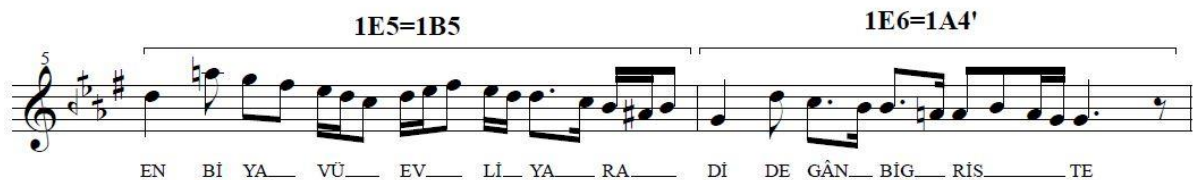

Şekil 11. 1E Cümlesi. 
Şekil 11'de 1E1 ölçüsünde gerdaniye perdesi vurgulanmış, 1E2 ölçüsünde bu vurgu devam etmiş ve iki ölçünün toplamında gerdaniye perdesi üzerinde rast çeşnisi oluşturulmuştur. 1E2 ölçüsünün sonunda tekrardan makamın kendi dizisinde yer alan nevâ perdesi üzerinde hicaz çeşnisi kullanılmış, bu çeşni 1E3 ve 1E4 ölçülerinde de devam etmiştir. Ayrıca şehnaz perdesi yerine muhayyer perdesinin kullanılması dikkat çekicidir. 1E5 ölçüsü 1B5 ölçüsü ile aynıdır. 1E6 ölçüsü ise 1A4 ölçüsünün birinci çeşitlemesi olup 1A4' şeklinde gösterilmiştir.

\section{8. “1.F Cümlesi”nin Analizi}

Birinci selâmın altıncı cümlesi olan 1F cümlesi altı ölçüden oluşmaktadır. Cümlenin dördüncü ölçüsü olan $1 \mathrm{~F} 4$ ölçüsünün dışında diğer ölçüler ya birinci selâm içerisinden başka bir ölçünün aynısı ya da bu ölçülerin birinci ve ikinci çeşitlemesi şeklindedir.
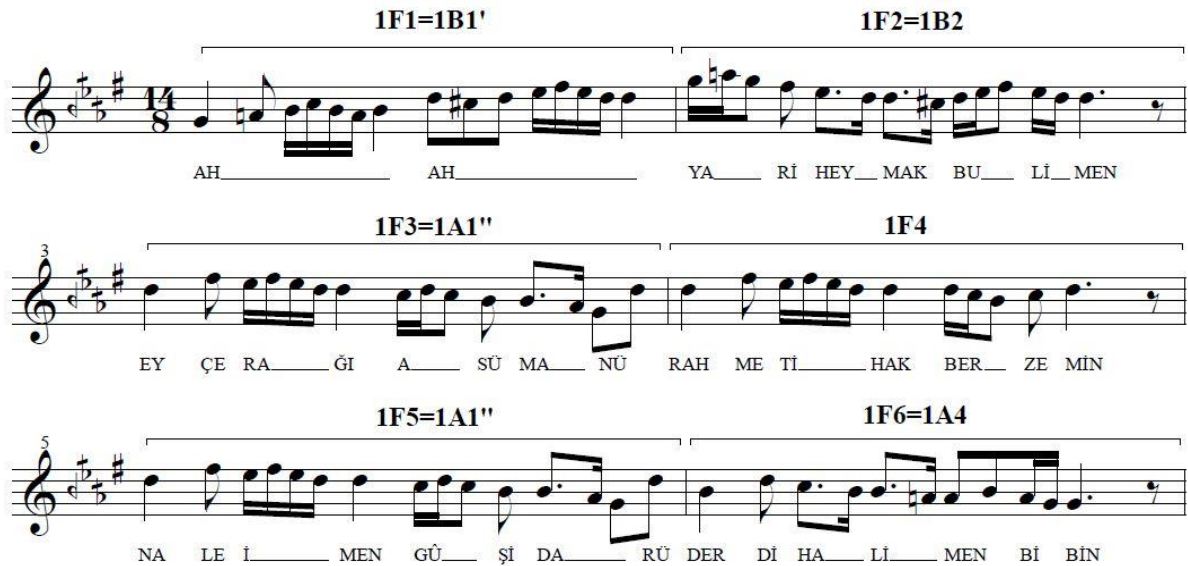

Şekil 12. 1F Cümlesi.

Şekil 12'de 1F1 ölçüsü 1B1 Ölçüsünün birinci çeşitlemesidir ve 1B1' şeklinde gösterilmiştir. 1F2 ölçüsü 1B2 ölçüsü ile aynıdır. 1F3 ölçüsü 1A1 ölçüsünün ikinci çeşitlemesi olup 1A1" şeklinde ifade edilmiştir. 1F4 ölçüsünde makamın güçlü perdesi üzerindeki hicaz çeşnisi gösterilerek yarım kalış yapılmıştır. 1F5 ölçüsü 1A1 ölçüsünün yine ikinci çeşitlemesidir. $1 \mathrm{~F} 6$ ölçüsü ise $1 \mathrm{~A} 4$ ölçüsü ile aynı özelliktedir.

\section{9. “1.G Cümlesi”nin Analizi}

Birinci selâmın yedinci cümlesi olan 1G cümlesi 14/8'lik yedi ölçüden oluşmaktadır. Fakat yapılan biçim ve melodik tekrar analizinden yola çıkarak son ölçünün yarısı $1 \mathrm{G}$ cümlesinin son ölçüsünü diğer yarısı ise $1 \mathrm{H}$ cümlesinin ilk ölçüsünü oluşturacak şekilde $7 / 8^{\prime}$ lik iki ölçüye bölünmüş ve bu şekilde analiz 
edilmiştir. Cümlenin ilk iki ölçüsü dışındaki beş ölçü biçim ve melodik yapı açısından farklılık göstermektedir.

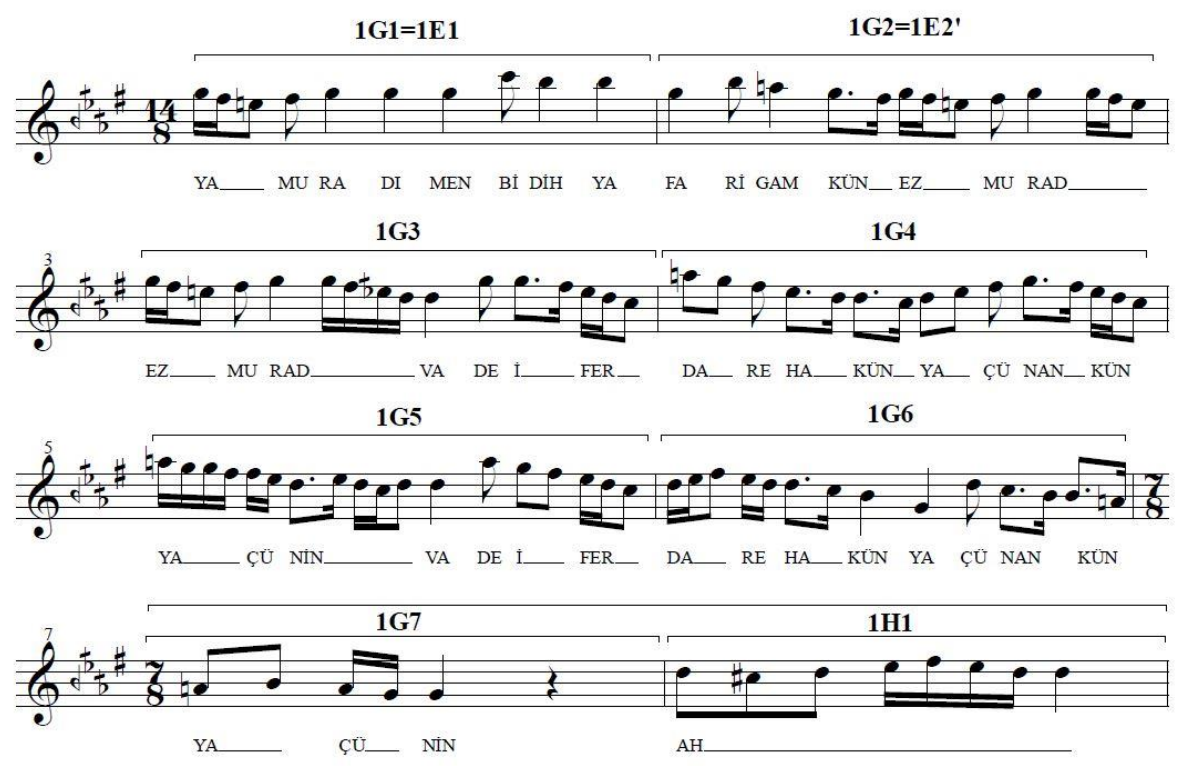

Şekil 13. 1G Cümlesi.

Şekil 13'te 1G1 ölçüsü 1E1 ölçüsü ile aynıdır. 1G2 ölçüsü ise 1E2 ölçüsünün birinci çeşitlemesi olup 1E2' şeklinde gösterilmiştir. 1G3 ölçüsünde nevâ perdesi üzerinde hicaz çeşnisi gösterilip ardından çargâh perdesinde nikriz çeşnisi ile kısa bir kalış yapılmıştır. $1 G_{4}$ ve $1 G_{5}$ ölçülerinde ise şehnaz perdesi yerine muhayyer perdesi kullanılarak yine nevâ perdesinde hicaz çeşnisi vurgulanmış ancak cümle sonlarında çargâh perdesinde nikriz çeşnisi ile kalış yapılmıştır. 1G6 ölçüsünde, önce rast perdesinde hicaz çeşnisi gösterilmiş hemen ardından ise zirgüle perdesi yerine dügâh perdesi kullanılarak $1 G 7$ ölçüsü ile birleştirilmiş ve rast perdesinde rast çeşnisi oluşmuştur. 1G7'nin ikinci 7/8'lik kısmı 1H1'i meydana getirmektedir.

\subsection{0. "1.H Cümlesi”nin Analizi}

1H cümlesine 14/8'lik ölçü bütünlüğünü korumak amacıyla $1 \mathrm{C}$ cümlesinin son ölçüsü olan $1 G 7$ ölçüsü de dâhil edilmiştir. Bu bölümde ölçülerin çoğu ya birinci selâm içerisinden başka bir ölçünün aynısı ya da bu ölçülerin birinci ve üçüncü çeşitlemesi şeklindedir. $1 \mathrm{H}$ cümlesi $1 \mathrm{~A}$ cümlesinin son ölçüsü olan $1 \mathrm{~A} 4$ ölçüsünün iki kez tekrar edilmesiyle bitmektedir. 


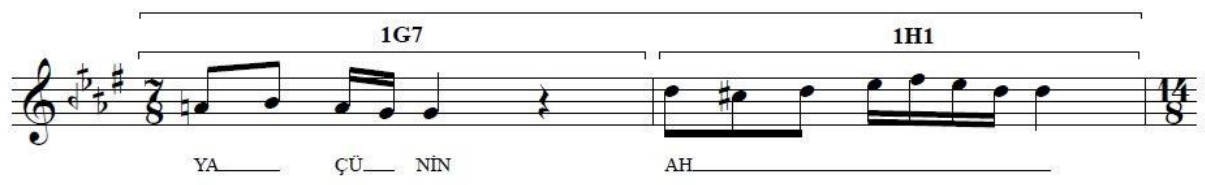

$1 \mathrm{H} 2=1 \mathrm{~B} 2$

$1 \mathrm{H3}=1 \mathrm{C} 3$

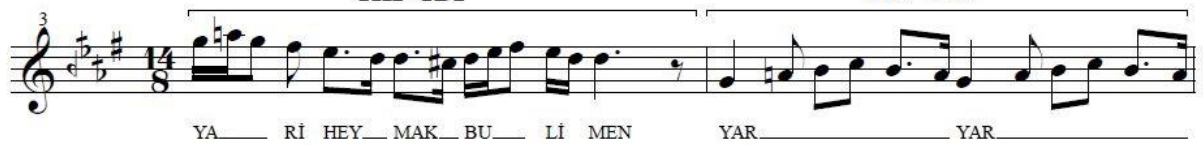

$1 \mathrm{H} 4=1 \mathrm{C} 4$

$1 \mathrm{H5}=1 \mathrm{C}^{\prime}$

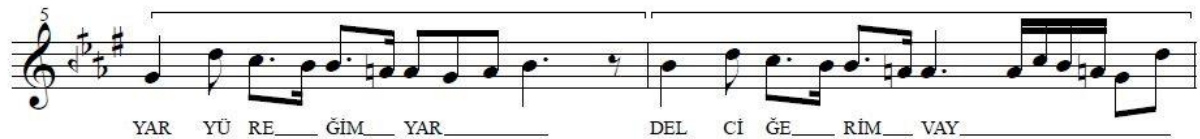

$1 \mathrm{H} 6=1 \mathrm{A1}{ }^{\prime \prime \prime}$

$1 \mathrm{H}^{\prime}=\mathbf{1 C} \mathbf{7}^{\prime}$

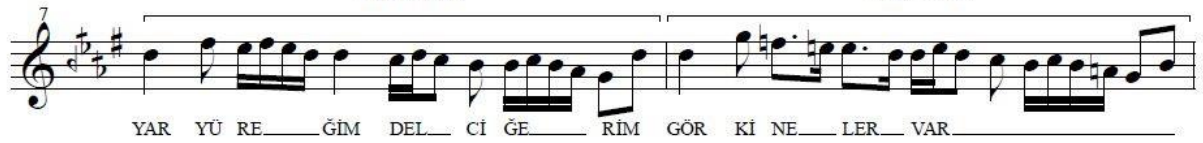

$1 \mathrm{H} 8=1 \mathrm{~A} 4$

1H9=1A4

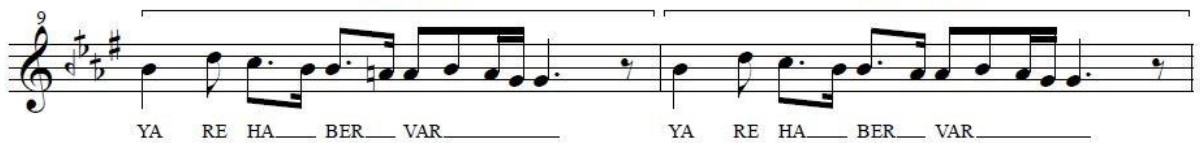

Şekil 14. 1H Cümlesi.

Şekil 14'te $1 \mathrm{H} 1$ ölçüsünde nevâ perdesinde hicaz çeşnisi kullanılmış ve nim hicaz perdesi ile yedenlenmiştir. $1 \mathrm{H} 2$ ölçüsü $1 \mathrm{~B} 2$ ölçüsü ile aynı özelliktedir. $1 \mathrm{H}_{3}$ ölçüsü ise $1{ }^{C} 3$ ölçüsünün birinci çeşitlemesidir ve $1 C_{3}$ ' şeklinde gösterilmiştir. $1 \mathrm{H}_{4}$ ölçüsü ile $1 \mathrm{C}_{4}$ ölçüsü aynıdır. $1 \mathrm{H}_{5}$ ölçüsü $1 \mathrm{C}_{5}$ ölçüsünün birinci çeşitlemesi olup 1C5' şeklinde ifade edilmiştir. $1 \mathrm{H} 6$ ölçüsü $1 \mathrm{~A} 1$ ölçüsünün üçüncü çeşitlemesidir ve 1A1"' olarak gösterilmiştir. $1 \mathrm{H} 7$ ölçüsü $1 C 7$ ölçüsünün birinci çeşitlemesidir ve $1 C 7^{\prime}$ şeklinde gösterilmiştir. $1 \mathrm{H} 8$ ve $1 \mathrm{H} 9$ ölçüleri ise $1 \mathrm{~A} 4$ ölçüsü ile aynı özellikleri taşımaktadır.

\section{Sonuç}

Sonuç olarak Necip Dede'nin sûzinâk âyininin birinci selâmında çoğu ölçü birbiri ile benzerlik göstermektedir. Birinci selâmda en çok rast perdesi üzerinde rast çeşnisi yaparak basit sûzinâk makamına sık sık atıf yapılmıştır. Ayrıca birinci selâmda makamın karara gidiş seyrinin özelliklerini taşımasından dolayı en çok 1A4 ölçüsünün tekrar edilmek sûretiyle kullanıldığı, çeşitleme olarak ise en çok 1A1 ölçüsünün tercih edildiği görülmüştür. Âyinde kullanılan makamsal yapılar Türk Mûsikisindeki zirgüleli sûzinâk makamı ile benzerlik göstermektedir. Makam genişlemesi "gerdaniye perdesinde rast çeşnisi" ile yapılmıştır ve simetrik 
genişleme kullanılmamıştır. Âyinde basit sûzinâk makamına yapılan atıf dışında iki makam dizisine daha geçki yapılmıştır. Bunlar; hüzzam ve inici rast makamı dizileridir.

\section{Kaynakça}

Ak, A. Ş. (2011). Türk Din Mûsikisi Cami ve Tekke Mûsikisi (2. bs.). Ankara: Akçağ.

Bayrakçı, Ö. F. (2015). Türk Din Mûsikîsi'nde “Mevlevî Âyini” Formuna Genel Bir Bakış, Eskişehir Osmangazi Üniversitesi Illahiyat Fakültesi Dergisi, 1, 139-152.

Çalışır, A. (2010). Beste-i Kadimden Beste-i Cedide (Meydan Görmüş). Mevlevî Âyinleri, Cilt 2, 40-42, Konya: Çizgi.

Karadeniz, Ş. (2013). Mevlevî Âyinlerinin Kompozisyon Açısından Incelenmesi. Yayınlanmamış Doktora Tezi. İstanbul: İstanbul Teknik Üniversitesi Sosyal Bilimler Enstitüsü.

Küçük, S. (2003). Mevlevîliğin Son Yüzyılı (1. bs.). İstanbul: Simurg. Özalp, N. (1992). Türk Mûsikîsi Beste Formları. Ankara: TRT. Özkan, i. H. (2008). Giriş, Fatih Salgar (yazar), Mevlevî Âyinleri. İstanbul: Ötüken. Öztuna, Y. (2006). Türk Mûsikîsi Akademik Klasik Türk San'at Mûsikîsi'nin Ansiklopedik Sözlüğü. Cilt 1-2, Ankara: Orient.

Tanrıkorur, C. (2003). Osmanlı Dönemi Türk Mûsikîsi. İstanbul: Ötüken. 